\title{
Genetisk betinget variasjon i bioaktivering av tamoksifen og klopidogrel
}

\author{
Noen legemidler må omdannes i kroppen til aktive metabolitter for å ha effekt. Genetisk variasjon medfører \\ ulik metabolismekapasitet og kan innebære manglende omdanning av legemidlet til aktiv substans. Dermed \\ er det fare for at noen pasienter ikke får tilfredsstillende virkning av livsviktige medisiner. For å unngå dette \\ mener vi at genotyping bør vurderes ved oppstart av slike medisiner.
}

Vigdis Solhaug

vigdis.solhaug@diakonsyk.no

Espen Molden

Prodrugs er legemidler som ikke har effekt i seg selv, men som må omdannes i kroppen til farmakologisk aktive substanser. Grunner til å administrere legemidler som prodrugs kan være å bedre stabilitet, absorbsjon og/ eller biotilgjengelighet av de farmakologisk aktive substansene (1). Ulike enzymer er involvert $i$ aktiveringen av disse legemidlene, deriblant esteraser og cytokrom P-450enzymer (CYP-enzymer) (tab 1). CYPenzymer er involvert i metabolismen av mange legemidler, hvorav enkelte er prodrugs med aktive metabolitter som skal forebygge alvorlige sykdommer/hendelser.

To prodrugs der effekten av behandlingen kan være kritisk for pasienters overlevelse er antiøstrogenet tamoksifen (Nolvadex), som brukes i kreftbehandling, og blodplatehemmeren klopidogrel (Plavix). Begge omdannes til farmakologisk aktive metabolitter via genetisk polymorfe CYP-enzymer, henholdsvis CYP2D6 (tamoksifen) og CYP2C19 (klopidogrel).

Hensikten med denne artikkelen er å vise hvordan genetisk variasjon i CYP-enzymer kan påvirke behandlingseffekten av disse legemidlene, samt å argumentere for at
CYP-genotyping er et nyttig verktøy for å forhåndsbestemme hvilke pasienter som vil ha best utbytte av behandlingen.

\section{Genetisk variasjon}

Enkelte pasienter har av genetiske årsaker manglende eller redusert evne til å omdanne tamoksifen og klopidogrel til aktive metabolitter. For CYP2C19, som omdanner klopidogrel til aktiv metabolitt, har for eksempel om lag 3-4\% av kaukasisk befolkning polymorfismer i begge alleler som gir inaktiv enzymfunksjon. I tillegg er ca. $30 \%$ av kaukasiere bærere av ett normalt allel og ett inaktiverende allel, og har dermed nedsatt metabolismekapasitet $(2,3)$.

Forekomsten av genvarianter som koder for endret funksjon av CYP2C19 og andre CYP-enzymer varierer med etnisitet. Hos asiatere er det for eksempel om lag $15 \%$ som har inaktiv CYP2C19-funksjon som følge av homozygote mutasjoner (3). CYP2D6 omdanner tamoksifen til aktiv metabolitt. Blant kaukasere mangler 5-10\% CYP2D6funksjon som følge av homozygot nedarving av inaktiverende variantalleler i dette genet. Videre er nærmere $40 \%$ heterozygote bærere av genvarianter som medfører nedsatt CYP2D6-funksjon $(4,5)$.

Også andre legemidler enn tamoksifen omdannes til aktive metabolitter via genetisk polymorfe CYP-enzymer. To kjente eksempler er kodein og tramadol. De må

Tabell 1 Eksempler på prodrug, aktiverende enzym og aktiv metabolitt

\begin{tabular}{lll} 
Legemiddel/prodrug & Aktiverende enzym & Aktiv metabolitt \\
Enalapril (Renitec) & Karboksylesterase & Enalaprilat \\
Dabigatraneteksilat (Pradaxa) & Flere esteraser & Dabigatran \\
Fosamprenavir (Telzir) & Alkalisk fosfatase & Amprenavir \\
Kodein (i f.eks. Paralgin forte) & CYP2D6 & Morfin \\
Tamoksifen (Nolvadex) & CYP2D6 & Endoksifen \\
Klopidopgrel (Plavix) & CYP2C19 & Klopidogrelmetabolitt \\
\hline
\end{tabular}

begge metaboliseres via CYP2D6 til henholdsvis morfin og $O$-desmetyltramadol, for å gi smertestillende effekt (4).

Mangelfull eller nedsatt funksjon av CYP2D6 og CYP2C19 kan også være et resultat av ikke-genetiske forhold, som kombinasjon med interagerende legemidler. Legemidler som hemmer CYP2D6 eller CYP2C19 vil gi redusert effekt av henholdsvis tamoksifen eller klopidogrel (6). Hemmere av CYP2D6 omfatter antidepressive legemidler som paroksetin, fluoksetin og bupropion, mens vorikonazol og omeprazol er aktuelle hemmere av CYP2C19.

\section{Klinisk betydning av CYP2D6 for effekt av tamoksifen}

Tamoksifen er en østrogenreseptormodulator som har godt dokumentert effekt $\mathrm{i}$ behandlingen av brystkreft. Legemidlet omdannes via flere trinn til metabolitten endoksifen, som primært medierer den terapeutiske effekten. Metabolisme av tamoksifen til endoksifen skjer hovedsakelig via enzymet CYP2D6, men andre enzymer bidrar også i noen grad (fig 1).

Pasienter med inaktiverende variantalleler i CYP2D6-genet oppnår redusert danning av endoksifen, og dermed redusert behandlingseffekt i form av økt risiko for tilbakefall av brystkreft $(6,7)$. I preparatomtalen til tamoksifen (Nolvadex) fremkommer det at hos pasienter med inaktiv CYP2D6-funksjon er endoksifenkonsentrasjonen $75 \%$ lavere enn hos pasienter med normal CYP2D6-aktivitet (6).

I en av de større studiene hvor man har undersøkt sammenhengen mellom CYP2D6genotype og klinisk effekt av tamoksifen, ble 1325 postmenopausale kvinner, inkludert $\mathrm{i}$ en retrospektiv analyse, behandlet med tamoksifen for østrogenreseptorpositiv brystkreft. Gjennomsnittlig oppfølgingstid var 6,3 år. Tilbakefallsraten var $29 \%$ blant kvinner som manglet CYP2D6-funksjon, sammenlignet med $14,9 \%$ hos de som hadde normal metabolismekapasitet. Det var altså en dobling i risikoen for tilbakefall ved manglende CYP2D6-aktivitet (8). 


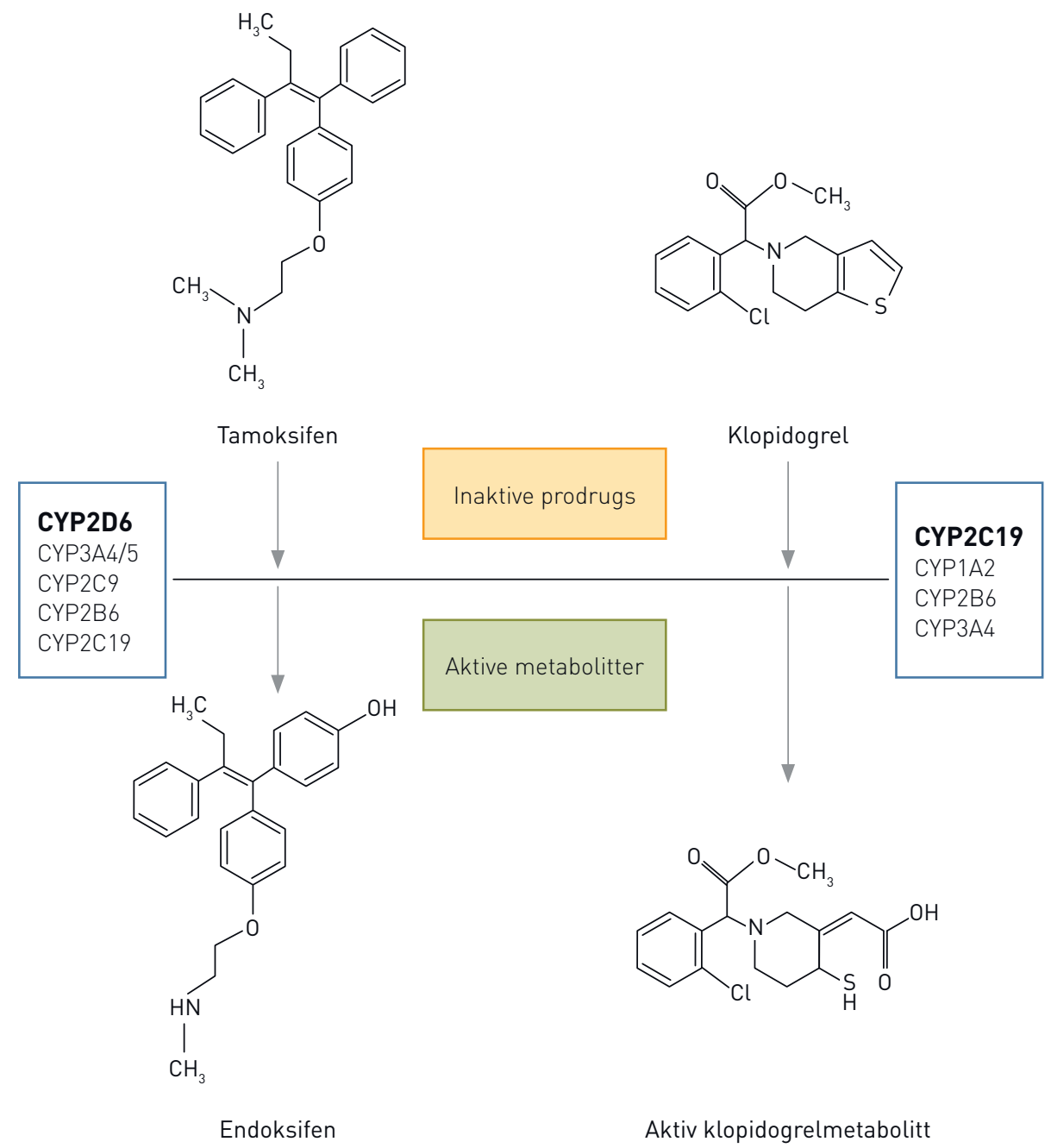

Figur 1 Tamoksifen og klopidogrel metaboliseres til aktive metabolitter via CYP-enzymer

I flere metaanalyser har man, basert på publiserte kliniske studier, evaluert sammenhengen mellom CYP2D6-genotype og utfallet av tamoksifenbehandling $(7,9,10)$. I en av disse hevder man at det ikke er nok evidens til å anbefale CYP2D6-genotyping for å styre tamoksifenbehandling (9), mens man i de to andre metaanalysene konkluderer med at genetisk variasjon i CYP2D6 er en viktig prediktor for utfall av tamoksifenbehandling $(7,10)$.

Ulike resultater i forskjellige studier kan ha sammenheng med studiestørrelse og oppfølgingstid, samt hvilken pasientpopulasjon som er studert, for eksempel før/etter menopause. I tillegg er det fremkommet bevis for at vevskilden til selve genotypingen har påvirket analysesvarene. De fleste individer bærer to kopier/alleler av CYP2D6-genet (et allel fra hver av foreldrene). Nylig ble det imidlertid dokumentert at opptil $45 \%$ av brystkreftsvulster mister ett av disse CYP2D6-allelene, et fenomen kjent som tap av heterozygositet. Dermed kan man ikke feste lit til de studiene hvor man har basert seg på genotyping av brystkreftvev. De store studiene med negativt resultat er i senere tid blitt sterkt kritisert for at man i dem baserte CYP2D6-genotyping på brystkreftvev og ikke nedarvet DNA fra friske blodceller/lymfocytter (11).

\section{Klinisk betydning av CYP2C19 for effekt av klopidogrel}

Flere CYP-enzymer er involvert i bioaktiveringen av klopidogrel, men CYP2C19 er hovedansvarlig (fig 1) (2). Sammenhengen mellom CYP2C19-aktivitet og serumnivå av den aktive klopidogrelmetabolitten er undersøkt hos friske personer (12). Sammenlignet med de som hadde normal CYP2C19-aktivitet, var serumkonsentrasjonen av aktiv klopidogrelmetabolitt henholdsvis ca. $30 \%$ og $50 \%$ redusert hos personer med ett eller to inaktiverende CYP2C19-alleler.

I mange studier har man undersøkt hvorvidt det er en sammenheng mellom nedsatt CYP2C19-aktivitet og manglende klinisk effekt av klopidogrelbehandling. I en av de første, publisert i New England Journal of Medicine, ble det observert en relativ risikoøkning på $53 \%$ for hjerteinfarkt, hjerneslag eller død hos personer med minst ett inaktiverende CYP2C19-allel (12). Denne studien ble utført på 1477 pasienter som fikk sekundærprofylaktisk klopidogrelbehandling ved akutt koronarsyndrom med utført perkutan koronar intervensjon (PCI) og stenting.

I påfølgende studier med varierende pasientpopulasjoner, størrelse og varighet er motstridende data blitt publisert vedrørende betydning av CYP2C19-genotype for behandlingseffekt av klopidogrel. Mens man i to metaanalyser fra 2011 konkluderte med at det ikke er signifikant sammenheng mellom CYP2C19-genotype og kardiovaskulære hendelser ved klopidogrelbehandling $(13,14)$, viste to nyere metaanalyser, med atskillig større pasientmateriale, en klar, $ø k t$ risiko for nye kardiovaskulære hendelser under klopidogrelbehandling blant bærere av defekte CYP2C19-alleler $(15,16)$. Den 
ene av disse metaanalysene (16) var basert på 20 studier med totalt 23000 pasienter, og viste om lag $50 \%$ økt risiko for kardiovaskulære hendelser hos de som hadde minimum ett defekt CYP2C19-allel sammenlignet med normale CYP2C19-omsettere.

\section{Genotyping bør vurderes}

Både tamoksifen og klopidogrel brukes for å forebygge alvorlige hendelser. Det er ingen rutinemessige monitoreringsmuligheter for vurdering av tamoksifen- eller klopidogrelrespons underveis i behandlingsløpet, og sviktende effekt vil først oppdages ved tilbakefall av ny svulst, eller ved ny kardiovaskulær hendelse. Vi mener derfor at det er essensielt å identifisere hvorvidt pasienten forventes å respondere på behandlingen, slik at eventuelle endringer i legemiddelvalg kan foretas for å sikre best mulig prognose.

Internasjonalt - se $w w w$.pharmgkb.org er det laget retningslinjer for dosering av en rekke legemidler relatert til genotype, inkludert om annen behandling bør foretrekkes $(3,17)$. Her fremgår det at postmenopausale kvinner med brystkreft, som har redusert eller ingen enzymaktivitet i CYP2D6, bør behandles med en aromatasehemmer fremfor tamoksifen. Aromatasehemmere er ikke indisert ved premenopausal brystkreft. Det har vært undersøkt hvorvidt dobling av tamoksifendosen til 40 mg daglig kan være en aktuell strategi hos pasienter med nedsatt eller ingen CYP2D6-aktivitet $(5,18)$. Hos de med ett inaktiverende $C Y P 2 D 6$-allel kan $40 \mathrm{mg}$ tamoksifen gi et endoksifennivå tilsvarende det normale CYP2D6-omsettere får med $20 \mathrm{mg}$, mens pasienter med to inaktiverende genkopier uansett får signifikant lavere endoksifenkonsentrasjon.

For klopidogrel anbefales det at bærere av ett eller to inaktiverende variantalleler i genet som koder for CYP2C19 bør startes opp på annen platehemmende behandling, f.eks. prasugrel eller ticagrelor. Dette er legemidler med tilsvarende farmakologisk virkningsmekanisme som klopidogrel, og preparatbytte anses derfor uproblematisk. Doseøkning av klopidogrel hos pasienter med nedsatt eller manglende CYP2C19aktivitet er begrenset dokumentert, og kan foreløpig ikke anbefales (3).

Siden tamoksifen og klopidogrel er prodrugs som må bioaktiveres via CYP-enzymer, vil effekten nødvendigvis bli dårligere ved manglende omdanning til farmakologisk aktiv metabolitt. Selv om resultater fra kliniske studier delvis er motstridende når det gjelder betydning av farmakogenetisk variasjon i respektive enzymer for behandlingsutfall, er det etter vår oppfatning en rimelig forsikring å utføre genotyping av CYP2D6 eller CYP2C19 ved oppstart med henholdsvis tamoksifen eller klopidogrel. Dette vil avdekke hvilke pasienter som vil respondere dårlig på behandlingen. Kostnadene til genotyping ligger, ifølge HELFO-takster, på ca. 400 norske kroner for CYP2C19 og 700 norske kroner for $C Y P 2 D 6$. Det er minimalt i forhold til behandlingsutgifter og pasientlidelser ved nye tromboser og tilbakefall av brystkreft forårsaket av terapisvikt.

CYP-genotyping er i dag en tilgjengelig analyse ved farmakologiske laboratorier ved flere norske sykehus, inkludert St. Olavs hospital, Oslo universitetssykehus og Diakonhjemmet sykehus. På nettsidene til Norsk portal for medisinsk-genetiske analyser www.genetikkportalen.no - kan man finne informasjon om hvilke laboratorier som utfører testene.

Vår oppfatning om at genotyping bør vurderes ved oppstart av behandling med tamoksifen og klopidogrel er i tråd med anbefalinger fra internasjonale konsensusgrupper $(3,17)$. Vi oppfordrer kardiologer og kreftleger i Norge til å vurdere implementering av disse anbefalingene $i$ aktuelle behandlingsprotokoller, og ta i bruk $C Y P$ genotyping som et redskap for å individualisere pasientbehandlingen.

\section{Vigdis Solhaug (f. 1975)}

er cand.pharm. og jobber med rådgiving og tolking av farmakogenetiske analyser og legemid delanalyser ved Senter for Psykofarmakologi, Diakonhjemmet sykehus.

Forfatter har fylt ut ICMJE-skjemaet og oppgir ingen interessekonflikter.

\section{Espen Molden (f. 1972)}

er forskningsleder ved Senter for Psykofarmakologi, Diakonhjemmet sjukehus, og professor II ved Farmasøytisk institutt, Universitetet i Oslo. Hans hovedfelt er farmakogenetikk og farmakokinetikk.

Forfatter har fylt ut ICMJE-skjemaet og oppgir følgende interessekonflikter: Han har mottatt honorar fra legemiddelfirmaene Boehringer, AstraZeneca og Novartis for undervisning av leger og annet helsepersonell om betydningen av interaksjoner og farmakogenetisk variasjon for effekt og bivirkninger av kardiovaskulære legemidler.
Litteratur

1. Rautio J, Kumpulainen $\mathrm{H}$, Heimbach $\mathrm{T}$ et al. Prodrugs: design and clinical applications. Nat Rev Drug Discov 2008; 7: 255-70.

2. Molden E. Genetikk og klinisk respons av antitrom botiske legemidler. Hjerteforum 2011: 24: 28-31.

3. Scott SA, Sangkuhl K, Stein CM et al. Clinical Pharmacogenetics Implementation Consortium guidelines for CYP2C19 genotype and clopidogrel therapy: 2013 update. Clin Pharmacol Ther 2013; 94: $317-23$

4. Crews KR, Gaedigk A, Dunnenberger HM et al. Clinical Pharmacogenetics Implementation Consortium guidelines for cytochrome P450 2D6 genotype and codeine therapy: 2014 update. Clin Pharmacol Ther 2014: 95: 376-82.

5. Irvin WJ Jr, Walko CM, Weck KE et al. Genotypeguided tamoxifen dosing increases active metabolite exposure in women with reduced CYP2D6 metabolism: a multicenter study. J Clin Oncol $2011 ; 29: 3232-9$

6. Statens legemiddelverk. Preparatomtale (SPC) Nolvadex, Plavix. http://legemiddelverket.no/ Legemiddelsoek (10.5. 2015)

7. Jung JA, Lim HS. Association between CYP2D6 genotypes and the clinical outcomes of adjuvant tamoxifen for breast cancer: a meta-analysis Pharmacogenomics 2014; 15: 49-60.

8. Schroth W. Goetz MP. Hamann U et al. Association between CYP2D6 polymorphisms and outcomes among women with early stage breast cancer treated with tamoxifen. JAMA 2009; 302: 1429-36.

9. Lum DW, Perel P, Hingorani AD et al. CYP2D6 genotype and tamoxifen response for breast cancer: a systematic review and meta-analysis. PLoS ONE 2013; 8: e76648.

10. Zeng Z, Liu Y, Liu Z et al. CYP2D6 polymorphisms influence tamoxifen treatment outcomes in breas cancer patients: a meta-analysis. Cancer Chemother Pharmacol 2013; 72: 287-303.

11. Goetz MP, Sun JX, Suman VJ et al. Loss of hetero zygosity at the CYP2D6 locus in breast cancer: implications for germline pharmacogenetic studies. J Natl Cancer Inst 2015; 107: dju401.

12. Mega JL, Close SL, Wiviott SD et al. Cytochrome p-450 polymorphisms and response to clopidogrel. N Engl J Med 2009; 360: 354-62.

13. Holmes MV, Perel P, Shah T et al. CYP2C19 genotype, clopidogrel metabolism, platelet function, and cardiovascular events: a systematic review and meta-analysis. JAMA 2011; 306: 2704-14.

14. Bauer T, Bouman HJ, van Werkum JW et al. Impact of CYP2C19 variant genotypes on clinical efficacy of antiplatelet treatment with clopidogrel: systematic review and meta-analysis. BMJ 2011; 343: $d 4588$.

15. Jang JS, Cho KI, Jin HY et al. Meta-analysis of cytochrome P450 2C19 polymorphism and risk of adverse clinical outcomes among coronary artery disease patients of different ethnic groups treated with clopidogrel. Am J Cardiol 2012; 110: 502-8.

16. Mao L, Jian C, Changzhi L et al. Cytochrome CYP2C19 polymorphism and risk of adverse clinical events in clopidogrel-treated patients: a metaanalysis based on 23,035 subjects. Arch Cardiovasc Dis 2013: 106: 517-27.

17 Swen JJ, Nijenhuis M, de Boer A et al. Pharmacogenetics: from bench to byte-an update of guidelines. Clin Pharmacol Ther 2011; 89: 662-73.

18. Welzen ME, Dezentjé VO, van Schaik RH et al. The effect of tamoxifen dose increment in patients with impaired CYP2D6 Activity. Ther Drug Monit 2015: 37: $501-7$.

Mottatt 13.5. 2015, første revisjon innsendt 3.11 2015, godkjent 20.1. 2016. Redaktør: Liv-Ellen Vangsnes. 